\title{
Abraham Abulafia's Mystical Theology of the Divine Name and its Philosophical Revision in Walter Benjamin
}

\author{
Michael T. Miller \\ University of Nottingham, UK
}

The thirteenth century kabbalist Abraham Abulafia held Hebrew to be the divine language, designed by God as an ontological aspect of reality. Through meditating on and deconstructing names into their letters, one could then engage in the process of reunifying reality into the primordial Name of God, the Tetragrammaton. This paper offers an original analysis, aligning Abulafia with Walter Benjamin's writings on language wherein the world speaks itself phenomenally to human beings, who must take an active role in translating this silent speech. Here the human, as name-giver, is finalizer of reality; by translating base phenomena into named entities humanity elevates them into a new realm, beyond the merely real into the true. This epistemic-soteriological theory speaks to common speculative questions about language and the world, offering a new way of understanding how human beings can come to know the world as-it-is, and as-it-should-be; a way that is philosophical, yet based firmly in Medieval Jewish theology.

KEYWORDS Abulafia, Benjamin, Kabbalah, Judaism, Language, Name, Messianism

This paper will look at two prominent figures of Jewish thought; the Medieval mystical theologian Abraham Abulafia (I240-C.I29I), and the modern German philosopher Walter Benjamin (I 892-1940). While separated by nearly 700 years, these two thinkers demonstrate the powerful influence that theology can have on philosophy, as well as how one can be used to transform and enhance the other.

Walter Benjamin claimed that the Kabbalah was a crucial influence on his thought. He once wrote that the introduction to On the Origin of German Tragic Drama could only be understood by one well-versed in Kabbalah. ${ }^{I}$ Through 
many conversations with his friend Gershom Scholem, he learnt about the currents of Jewish mysticism and its doctrines regarding the nature of language. One of the most important thinkers that Benjamin absorbed from the research of Scholem was the thirteenth century kabbalist Abraham Abulafia. ${ }^{2}$ The deep interest in language is shared by Benjamin and Abulafia, and for them it is one that goes through the whole course of creation, encompassing not only its initial conditions but its most basic ontology and even the messianic redemption.

In this paper I will argue that across a gulf of 700 years, Benjamin presents the logical conclusion of the mystical doctrines developed in the thirteenth century, by Abraham Abulafia. I will begin by highlighting some similarities between Abulafia's and Benjamin's views of natural language, then explore some differences, before finally tying them together with an attempt to show that Benjamin's messianism is actually a substantially enhanced restatement of Abulafia's own.

\section{The nature of language in Benjamin and Abulafia}

For millennia, language has held a special place in Jewish thought. Perhaps most notably, in the biblical text God speaks the world into existence, naming light, dark, and the heavens, and bestowing His blessing on the creation that He finds 'good'. And so, 'through ten utterances was the world created', as the common rabbinic edict has it. ${ }^{3}$ During the early rabbinic era, speculation on language strengthened this notion, perhaps culminating in the doctrines of Sefer Yetzirah, which claimed that all existence is the result of God combining (Hebrew) letters such that 'all creation and all speech go out by one name' (\$I9). ${ }^{4}$

In a discussion of language in the text $20^{\text {th }}$ Century Jewish Religious Thought, Josef Stern claimed that in this way Genesis is a commentary on the nature of language as much as it is on creation. What was previously the 'amorphous lump' of reality emerged into discrete objects through a process that we might call articulation: 'creation is their [objects'] emergence through separation and division. But by

\footnotetext{
${ }^{\mathrm{I}}$ Wolin, R., I994, p. 37 .

${ }^{2}$ On which, see Idel, M., 20I0, pp. I 68-75. The exact nature of the exchange of ideas between Benjamin and Scholem is disputed, as Idel discusses. Eric Jacobson, 2003, pp. 85-89, finds the source of the pair's philosophy of language in Late Antique rabbinic discussions, and Genesis Rabbah's claim on the Torah as pre-existent archetype of the world. Susan Handelman, I99I, pp. 7I-78, offers a different analysis, placing both Scholem and Benjamin under the aegis of a German Romantic view of language, ultimately descending from the seventeenth century debates about Adamic language; which itself apparently drew upon kabbalistic ideas that had filtered into Christendom during the Enlightenment.

${ }^{3}$ E.g., b. Rosh Hashanna 32 a.

${ }^{4}$ On language as medium of creation in Judaism, see Idel, M., 2002, and Weiss, T., 2007, pp. I69-200. In a more recent paper, Weiss has argued that the mythical role of language or letters in creation is not uniquely Jewish but rather is a frequent motif representing the powerful fascination that language holds for human beings. So,
}

[...] in several cultural contexts of Late Antiquity, there was no doubt that the world had been created from letters [. . . furthermore] in ancient Greece, independent of Semitic conceptions concerning the importance of alphabetic signs, the word stoicheion ( $\sigma \tau \mathrm{o} \chi \varepsilon$ íov) was used both to refer to letters and to signify the physical foundations of the world.

See Weiss, T., 2009, p. I02.

In fact, it is the Greek word stoicheion that demonstrates the shared 'atomic' nature of both reality and language. This conclusion is also supported by Kieran Barry, I999. 
integrating acts of speech and naming into the sequence of creation, the Torah suggests that how the world presents itself, divided into objects and structured into kinds, is also inseparable from language'. ${ }^{5}$ In this reading, names are not just descriptors, applied to ontologically pre-existent objects, but are 'the expression of the criteria of individuation and identity, without which there would be nothing to be named'. ${ }^{6}$ In God's hands, words do not merely describe but determine the world: 'language is not merely descriptive but constructive of reality, outside rather than within nature, aligned with the creator rather than the created'. Stern writes that in this biblical-rabbinic conception, 'words, especially proper and common names, do not arbitrarily refer or apply to individual things or categories; they refer to them by virtue of expressing their natures or essences,' and so, 'names [...] abbreviate descriptions of the essences of their bearers'.

Supporting this idea, in Genesis 2:19-20 God brings the animals and birds that $\mathrm{He}$ had formed before Adam, in order for Adam to name them. In this passage, unlike the initial narrative of creation, it is not God but the human who names. Adam here takes the role of overseer, providing titles to the animals - but Jewish tradition has emphasized that these names are not arbitrary; part of Adam's unique power in this role is that he furnishes the correct name for each animal. ${ }^{7}$ This is even implied by the biblical text: the verb קרא, used here to mean 'to call/name,' also means to read out. Therefore, when Adam names, he is not merely applying an arbitrary sign to the object, but is interpreting its being into words: he 'reads' it.

In these passages language is able to determine the truths of reality: where in the first instance it is utilized as a tool to create, defining the world and its elements into existence, another implication is brought out in the second: the nature of reality is encoded in the words that describe it, and is therefore accessible to humans through the mediation of language.

Here, we can turn to the kabbalists. Gershom Scholem located the beginnings of Jewish language-mysticism at the point where the creative word used in Genesis became identified with God's Name, and so the nominative identity of God became fused with the function of language - itself a realm far beyond mere communication. ${ }^{8}$ This is a basic precept of much early kabbalistic thought. Kabbalah is traditionally articulated into two distinct traditions - one linguistic, based on the knowledge of God via His names, and one theosophical, based on the knowledge of God via His presence in creation (i.e., through the sefirot). ${ }^{9}$ For the kabbalists,

\footnotetext{
${ }^{5}$ Stern, J., 2009, p. 543 .

${ }^{6}$ Ibid., p. 544 .

7 This is supported by the rabbinic discussions in e.g. Ber.Rab.17:4, Pes.Rab.I4:9; in these passages the angels, given the first turn, had managed to fail at the task of giving names.

${ }^{8}$ Scholem, G., I972, p. 70; 1973, pp. I64-94. Scholem admitted not knowing at what point this identification occurred, and although Jarl Fossum offered an early date in his The Name of God and the Angel of the Lord: Samaritan and Jewish Concepts of Intermediation and the Origin of Gnosticism (1985), the analysis is not conclusive and has been subject to challenge. See Miller, M.T., 20I 5. What is certain is that it had occurred before the Kabbalah and formed a crucial aspect of kabbalistic cosmology.

${ }^{9}$ This polarity of the nominal-linguistic and the sefirotic kabbalahs was first made by no less than Abraham Abulafia in a letter to Judah ben Salomon, from the late I 280 s. On this, see Wolfson, E.R., 20I I, pp. 68-90. The distinction, however, is somewhat deceptive as the sefirot themselves can be understood as manifestations of God's names; each is assigned a biblical title and in some thinkers the sefirot in toto constitute the single Name of God, YHWH.
} 
language was not only 'the essence of the universe', but was also metaphysically derived from the Name of God which is 'the basis of all spoken language'. ${ }^{\circ}$

Abulafia and Benjamin heavily emphasize the notion of an original or natural language, though in slightly different ways. For Abulafia this is Hebrew, the tongue that spoke the world into existence. ${ }^{\text {I }}$ Words, names, are a fundamental part of reality: they have a direct relationship to objects because the Hebrew name of something is linked to its essential nature, encoding that nature in a form which is discoverable by human beings. Abulafia writes that names 'inform us about the truth of the mysteries of language, and its secrets', names are given 'according to the nature', ${ }^{2}$ 'for anything in existence, its form corresponds to the name that nature bestowed upon it; for the form, name, and concept are identical', ${ }^{13}$ and 'The noun indicates [an object's] substance and essence'. ${ }^{\text {I4 }}$

But Abulafian names are not descriptive in the usual sense; rather they should be understood technically, as the literal identity of objects. As such, things are materially constituted of letters, and it is the letters that are the essential atomic components of reality; these are the elements that God shapes into objects, and 'letters are the reality of the world entirely, and by means of them the Lord governs the world'. ${ }^{15}$ Here, then, words are the essence of the things they refer to and the literal construction of a thing's name can be decoded as can the DNA sequence of an animal.

In Benjamin's extensive and unsystematic writings we find several times he returns to the issue of language. ${ }^{\mathrm{I}}{ }^{6} \mathrm{He}$ writes that 'Language is [...] the mental being of things', and is coextensive 'with absolutely everything' ${ }^{17}$ He hedges this by expanding the definition of language, claiming that:

Language in such contexts means the tendency inherent in the subjects concerned-technology, art, justice, or religion-toward the communication of the contents of the mind. To sum up: all communication of the contents of the mind is language, communication in words being only a particular case of human language. ${ }^{18}$

But at the same time he emphasizes that 'This use of the word 'language' is in no way metaphorical'. ${ }^{19}$ This deeper, non-vocal strata is still essentially in the form of language-or rather, human vocal language always follows in its form, as one specific expression of reality's semantic essence. There is an unworded, unspoken, language of literal description deep within the structure of the world. So for both Benjamin

\footnotetext{
${ }^{10}$ Ibid., p. 63.

${ }^{11}$ Hebrew is 'natural' in the sense of being in accord with nature; but Abulafia rejects the idea that humans can or would speak Hebrew naturally, without instruction; the knowledge of Hebrew is by convention, even though its relation to the world makes it wholly accurate. For more on Abulafia's conception of Hebrew, see Idel, M., I989, pp. I2-27, and Wolfson, E.R., 2000, $58 \mathrm{ni} 66$.

${ }^{12}$ Sefer ha-Melammed (MS Paris-BN heb. 680, fol.296a) (Trans.) Wolfson, Abulafia, p. 63.

${ }^{13}$ Sefer Chayyei ha-Nefesh, trans. Idel, M., Language, Torah and Hermeneutics, p. I47.

${ }^{{ }^{1} 4}$ Sefer 'Or ha-Sekhel, ibid.

${ }^{15}$ Sefer ha-Hesheq (MS NY-JTSA Mic.I80I, fol.ı 9 b) (Trans.) Wolfson, Abulafia, p. 6o, footnote I7I.

${ }^{16}$ See, e.g., Hanssen, B., 2004, pp. 54-72. An analytic interpretation of Benjamin that largely agrees with my own analysis has recently been given in Procshyn, A., 20I4, pp. 368-8I.

${ }^{17}$ Benjamin, W., I996, p. 66.

${ }^{18}$ Ibid.

${ }^{19}$ Ibid.
} 
and Abulafia, verbal language is itself only a highly attuned expression of a deeper linguistic structure which goes right to the root of existence.

We may characterize Abulafia's approach to language as one that is somewhat passive - objects can be read, and their secret nature decoded, but that is the extent of human involvement. Language is a tool of God, and humans can at most reverse-engineer the process of creation in order to decode its secrets. But for Benjamin things are different. He argues that the reading of nature is not a passive reception of objective truth, but rather, an active process that coincides with the construction of phenomenal reality; language then is the coming together of nature and humanity, in knowledge. In order for the world to be read, it must speak itself and be heard. In other words, its capacity to speak itself is its capacity to be known. This notion is related to Benjamin's anti-idealism, to his rejection of the unity of appearance and being, of a reality with its idea, or of an object with its name: Benjamin explicitly rejects this aspect of kabbalistic thought, claiming that the mystical theory of language that 'the word is simply the essence of the thing [...] is incorrect, because the thing in itself has no word' ${ }^{20} \mathrm{He}$ describes this theory as 'the great abyss' that we must avoid at all costs. ${ }^{2 \mathrm{I}}$ There is a necessary separation that we must take into account here: while the language of an object is only what is expressible by that object (and not the object itself), that language always occurs in communication with the human subject. Because what can be read - or heard - by human beings is not the essence of an object but only what is communicable to humans, human language must always be something of a misreading, or a translation. The language of nature depends on the interpretative action of humans to complete it; and for Benjamin, this interpretative action is one of naming. We create nominal references based on the phenomenal presence of the object and so there is an ineluctable element of humanity embedded in our interpretation, imposing a subtle play of difference between an object and its name. Humankind must transform this base phenomenal expression into final, verbal language. Names, therefore, are not provided by the world but depend on being processed by humanity. The name, then, is the aspect of the object which is the object-for-human.

God did not create man from the word, and he did not name him. He did wish to subject him to language, but in man God set language, which had served him as a medium of creation, free. God rested when he had left his creative power to itself in man. This creativity, relieved of its divine activity, became knowledge. Man is the knower in the same language in which God is creator. God created him in his image, he created the knower in the image of the creator. ${ }^{22}$

So unlike Abulafia's Hebrew, Benjamin's natural language itself contains no words and is not already complete. Rather it depends on human beings to complete it. The human, in giving names to things, is effecting this completion. While Adam reads the animals and then produces the correct names for them, the names are not

${ }^{20} \mathrm{Ibid}$., p. 69. He speaks also of the 'nameless, unspoken language' of nature.

${ }^{21}$ Ibid., p. 63 .

${ }^{22}$ Ibid., p. 68. 
what those beings communicate to him: humankind must transform the base phenomena into a final, vocal language of names.

\section{Abulafia's source of language: The divine name}

I have mentioned above Abulafia's emphasis on letters over words; words should not be understood in terms of a semantic meaning, but rather as constructions of the prima material, the Hebrew alphabet. So he argues for a deconstructive approach to language, claiming that the mystic should meditate on words in order to break them into the letters that constitute them and to expose the internal relationships between different words - and therefore between objects. ${ }^{23}$

For Abulafia, this manipulation of letters - or tzeruf otiot - is a real metaphysical process, one of going beyond the concrete forms that surround us, dissolving actual objects, via the intellect, into their primal constituents. It is only via the deconstruction of names that humans can access the fundamental atoms of reality, the letters. ${ }^{24}$

In performing this process, one goes beyond the forms of reality and stratifications of everyday perception, into a more primal realm. ${ }^{25}$ By deconstructing words we can progress backwards towards the primal unity that the kabbalists believed stood at the head of reality: God's own Name, the Tetragrammaton, which predates and transcends the world. The means of finding this relationship is only possible through tzeruf otiot. Once letters are untied from the objects they appear in, they undergo an entropic process, reforming into their root, God's Name. ${ }^{26}$ Therefore, by manipulating names into letters, one can begin a mystical reversion of the process of emanation, and in doing so the true function of language is unveiled: 'the intent behind language is the discovery of the function of the Active Intellect'. ${ }^{27}$

\footnotetext{
${ }^{23}$ These relationships are near-exclusively mathematical: Hebrew letters have numerical values and it was common practice for kabbalists to equate the meaning of words that had the same sum value, or to see relations based on the mathematical permutations s of words. This process is known as gematria, a term descended from geometry. Recent research suggests that this etymology may point to an extra-Judaic history of the method; Kieren Barry's, The Greek Qabalah, I999, argues that it was originally a Greek development.

${ }^{24}$ See the aforementioned article by Weiss, T. 'On the Matter of Language', 2009, which provides a Lacanian interpretation of this motif.

${ }^{25}$ Abulafia instructs us to 'Separate [the elements of] the words, for at times a name may consist of even only one letter, which is regarded as if it were one whole word. This tells us that each letter is a world unto itself, according to the Kabbalah'. Peras haSefer, Idel, M., 2008, p. 23.

${ }^{26}$ Abulafia's contemporary (and possibly student), Yosef Gikatilla, developed a systematic cosmological explanation of how the Name YHWH could articulate itself through various mathematical permutations into, first, the other names of God given in scripture, and from there to every word which together constitute the text of the Torah, that is, the blueprint for reality. Gikatilla's is only the most fully articulated version of a view which was common currency in twelfth-thirteenth century Kabbalah, and that it is one Abulafia shared can be evinced by his statement that,
}

[...] the whole world is dependent on it [YHWH], it is the beginning of all beginnings and the purpose of all purposes, and it is the ineffable Name one in all manners of unity [. . . And it is YHWH [...] and know that this blessed Name includes all the other divine names and all emerge from it.

See Abulafia, A., 2007, p. 30. On Gikatilla's system, see especially Blickstein, S., I983, as well as Morlok, E., 20 I I.

${ }^{27}$ Mafteach ha-Chokbmot, (Trans.) Idel, M., I989, p. 22. The Neoplatonic concept of the Active Intellect, indicating the rationality behind the visible world and analogous to the earlier logos was adopted first by the Arab philosophers and from there the kabbalists. For the kabbalists, the Active Intellect was identical with the Torah and the archangel 
As he puts it in another text, 'You should bind together all of the letters with the letters themselves, for they are the roots of all their existence according to what they indicate, for all of the bodies are signs by which to discern through them the Name as well'. ${ }^{28}$ God's Name is ever-present in the world, although buried deep beneath the surface forms that we perceive. In transcending the object-identities of the apparent world, the mystic can reach beyond phenomenal consciousness into a more unitary realm. Moreover, the realization and expression of the true Name of God is something that can only be achieved by the Messiah, for it is one that is concealed by the Tetragrammaton, and shall re-enter the world as the culmination of the messianic process:

$[\mathrm{N}]$ ature is the activity-function of the Blessed Name and is the corporeal existence, whereas the Torah is the activity-function of the Blessed Divine Name and is the spiritual existence. Physical and spiritual existence are nothing more than systems and orders, ordered and systematised in accordance with all that is ordered and systematised by the One who orders and systematises. For the systematiser is the Name, and all is ordered in accordance with the Name of God. ${ }^{29}$

This method of prophecy then allows us to trace the means of causality back from the visible world to its logical cause, the structural predecessor that is the divine realm, the Divine Name. Breaking things into pieces, those pieces fall into their initial state as the Tetragrammaton. By investigating the intellectual nature of the natural world, the structure that generates it can be found. This is Abulafia's prophetic and messianic process; the mystic in ultimately meditating on God's Name, becomes united with it in the form of a portal through which divine truth can directly re-enter the world.

By dissolving the entities of the visible world back into their constituents, one can perceive the radical unity - the Name - which lies within and above them. This is what Idel calls the murder of language, ${ }^{3 \circ}$ because one must 'Read the entire Torah, both forwards and backwards, and spill the blood of the languages. Thus, the knowledge of the Name is above all wisdoms in quality and worth'. ${ }^{3 \mathrm{I}}$ Abulafia wants to take hold of language and cut it into its smallest parts in order to see past the apparent existences of this world and to their primordial root. This untying of worldly identities frees the atomic letters to reunite as the Name, which

Metatron; and the Tetragrammaton YHWH. Abulafia writes that the Torah 'is a name referring to the Active Intellect, which is called the Word of God, or the Spirit of God, or His Speech or His Name or His Glory, for it instructs the sages of the Name, in the knowledge and comprehension of Him'. (Wolfson, E.R., 2000, p. 36. See also Idel, M., I989, p. I I I.

${ }^{28}$ Perush haSefer Yetzirah, (Trans.) Wolfson, E.R., 'Doctrine of the Sefirot', II, 58. Emphasis mine.

${ }^{29}$ Otzar Eden Ganuz, (Trans.) Idel, M., I989, p. 35.

$3 \circ$ Abraham Abulafia (2000).

Abulafia clearly expresses the idea that only by breaking apart the conventional form of words can one attain a higher level of knowledge, i.e., knowledge of the Name of God [. . .] Only by means of the murder of the languages, the spilling of blood, can one attain to the knowledge of the Name.

See Ibid., p. 27.

${ }^{3 \mathrm{I}}$ Perush Sefer Ish Adam, ibid. 
is their natural originary form - the $\mathbf{2 2}$ letters of the Hebrew alphabet are released and reform into their root in the Tetragrammaton. ${ }^{32}$

\section{Benjamin's source of perception: Concept and idea}

Now, I will argue that Benjamin takes this deconstructive method as the basis of his philosophy of language, but inverts the Messianic direction. I mentioned the interpretative action of consciousness that takes place in the translating of the world into a subjective phenomenon. Benjamin argues that in this process, the phenomenal must be broken into its constituents in order to be reformed not as what it is but as what it should be:

Phenomena [. . .] do not enter the realm of ideas whole, in their crude empirical state, adulterated by appearance, but rather [are] redeemed only in their elements. Broken up into parts they are deprived of their false unity in order to take part in the genuine reality of truth. In this their disintegration, phenomena are subordinated to their concepts; the latter are what bring about the dissolution of things into their elements. ${ }^{33}$

Forming a concept of a phenomenon analyses it into its elements, but creating an idea from those elements then reforms those elements into something new, and something that is both eternal and transcendent - part of the intellectual strata that is the 'genuine reality of truth'. In The Origins of German Tragic Drama, Benjamin argues that an idea has the same relationship to the phenomenon that it represents, as a constellation does to the stars it contains: 'Ideas are timeless constellations and by virtue of the elements' being seen as points in such constellations, phenomena are subdivided and at the same time redeemed'. ${ }^{34}$ As Richard Wolin explains: 'It is only upon being dissolved into their constituent elements that phenomena are first rendered fit for the ultimate philosophical reordering in the redemptive embrace of the constellation, for the latter consists of nothing more than the simple rearrangement of these elements themselves'. ${ }^{35}$

This is the retranslation of the base material of the phenomenal into the intelligible. The intelligible representation, though, does not incorporate the object itself: rather, it signifies it. The object itself - including its material aspect that simply is, and is not communicable, being non-linguistic - remains, it is not destroyed by this process of translation. This redemptive translation into the intelligible realm is identical with the process of naming: 'The translation of the language of things into the language of man is not only a translation of the mute into the sonic; it is also the translation of the nameless into name'. ${ }^{36}$

\footnotetext{
32 'Know in truth that the comprehension of the Agent Intellect is found within the twenty-two holy letters'. (Trans.) Idel, M., 2008, p. I I. He argues that Abulafia may have understood the term Jew (יהודי) 'as an allegory for the perfect knowledge of the divine name' (p. 22). It seems that Abulafia also interpreted the 'name' AHWY as related to this process, owing to its gematria value of 22. This name may be the secret, Messianic Name that Abulafia saw himself as expounding.

${ }^{33}$ Benjamin, W., I977, p. 33.

${ }^{34}$ Ibid., p. 34 .

35 Wolin, R., 1994, pp. 94-95.

36 'On Language', p. 70.
} 
So the name is not the object, but is from the object, as the geometric relationship between points is from the object that defines those points.

The misreading that is a name can take us further, away from the merely real, and into the true. Naming is a step away from the simple essential being of things, and into a new realm. The creation of name is the refusal of a being's reduction to facts, and the admitting of a being which transcends facts. The abstract relationship between points can continue 'existing' in whatever sense it does even after the points themselves have ceased. It takes us away from the insignificant natural world and begins the generation of a metaphysics - that practice by which alone redemption is possible. This is 'the task of the coming philosophy', which is:

[...] the discovery or creation of the concept of knowledge which, insofar as it relates the concept of experience exclusively to the transcendental consciousness, renders possible not only mechanical but also religious experience. Which is not to say that knowledge renders God possible, but rather that it first makes the experience and doctrine of God possible. ${ }^{37}$

For both thinkers, then, we can understand the name as the final stage in the world's emergence into being; the name is that construct that unites discrete elements into a whole, into an object that is conceived by human beings. But, whereas Abulafia sees the name as the external nature that humanity should deconstruct in order to go behind the phenomenal, down to the roots of reality that are the Hebrew letters, for Benjamin the process of naming as a step away from the disjunction of raw nature is itself part of the goal: naming takes humans not back and down into the roots of reality, but up and forward into the divine realm that the human activity projects. Thus, 'God's creation is completed when things receive their names from man'. ${ }^{38}$

For Benjamin, this process of translating, or naming, provides both the meaning of the linguistic being of the world, and the meaning of human consciousness. The fact that 'Adam' is used as a proper name for the first time only at Genesis 2:20 (as opposed to the previous ha-adam, 'the man'), which is the point when he is naming other things, suggests to Benjamin that Adam's full individuality is corollary to (and dependent upon) the fulfilling of his role as namer, as the one who completes creation by providing the names for its elements. So, 'Man [...] communicates his own mental being [...] by naming all other things'. ${ }^{39}$ In fact, language is the totality of humanity's mental being where this mental being is then uniquely 'communicable without residue, ${ }^{4 \circ}$ and it is the very mental being of humans to name things; which is to say, to translate their mental being into names.

This naming is not humanity merely knowing the correct names of things; it is not a passive understanding of the nature of things; it is rather the giving of correct names. Benjamin writes that nature itself speaks in 'a nameless, unspoken language', so in itself, the thing is nothing - it is simply an aggregate, a kind of formless chaos

\footnotetext{
${ }^{37}$ Gesammelte Schriften 2, p. I64, cited in Wolin, R., I994, p. 35.

38 'On Language', p. 65.

${ }^{39} \mathrm{Ibid}$., 64 .

${ }^{4 \circ}$ Ibid., 65 .
} 
that requires articulation into identity by some other. To be a thing, it must speak and be heard; and it is the peculiar role of humanity to translate the silent speech of a thing's being into its name. Humanity then acts as the finalizer of the linguistic process of being, by stating - not repeating - the names of the world.

For Benjamin, naming does not constitute access to objects, but their liberation; their liberation even from subjectivity - for ideas are the 'objective interpretation' of phenomena. ${ }^{4 \mathrm{I}} \mathrm{It}$ is only in the translation into idea that an object 'becomes something different: a totality'. ${ }^{42}$ The name is a 'state of being beyond all phenomenality' that 'determines the manner in which ideas are given. But they are not given so much in a primordial language as in a primordial form of perception, in which words possess their own nobility as names, unimpaired by cognitive meaning'. ${ }^{43}$ Here, Benjamin titles this intentionless, meaningless quality of naming as the 'primordial form of perception': that which undergirds any more developed and evolved perception that founds conventional living.

The suggestion here is that there is a semantic, though prelinguistic, nature to reality, one to which the human mind is attuned - or even, isomorphic - in order to express this nature linguistically. There is a pure language of nature that speaks itself to any who will hear. But the final manifestation of that reality comes with its transformation into the intellectual Name-Language of human beings. And really this is not that different from other more finely tuned philosophy of language, thinkers like Frege and Wittgenstein, who both argued that sentences in human language are merely expressions of the material nature of the world; or as they would put it, propositions exist independently of the buman mind, in the world. ${ }^{44}$ It is worth pointing out that to say this is not necessarily to say that there must be a distinction between such a semantic substructure in nature, or in the stuff of mind itself; it is merely claiming that the deep structure of the reality which is perceived is essentially semantic, is patterned according to the logic that facilitates language.

\section{The 70 languages and the single language}

There are other implications to this, which Benjamin discusses in terms of translation and the multiplicity of languages. I have mentioned that there is the idea of an underlying semantic logic in nature, which the mind picks up on in order to form rational ideas from - or names, depending on how you want to think of it. Benjamin argues that manifest human languages - German, Russian, English -

\footnotetext{
${ }^{41}$ Benjamin, W., I977.

$4^{2}$ Ibid., p. 46.

${ }^{43}$ Ibid., p. 36.

${ }^{44}$ For the early Wittgenstein, and based largely on his reading of Frege, propositions, being written into the nature of objects, exist outside the human mind and are fundamental, primary, constituents of reality - the possibilities that the human mind accesses and must match up against the empirical world in order to ascertain their 'truth' via their similarity to that world. See Brockhaus, R.R., I99I, p. I62. For these thinkers, it is not propositions that express thoughts, but thoughts that express propositions. That this is the case is a large part of why the empirical world is so perfectly describable in linguistic terms, because propositions are formally identical with the facts they represent in the world. This means that language is not just isomorphic with the world, but springs from the same root; language, in its propositional nature, is identical with the relationships between objects in the world.
} 
act as a mere expression of the underlying semantic logic that is the logic of language, singular. And in some ways this reflects the long-standing Jewish tradition of 70 languages, one for each nation, but each of which is ultimately descended from Hebrew - the original language of creation, which Adam and Eve spoke. ${ }^{45}$ The 70 languages of Jewish tradition, then, in this reading of Benjamin, are diffracted aspects of the single language, which itself is not $a$ language but only the possibility of language, encoded into the interpretation of reality.

Benjamin claims that 'the language of things [that is, the natural language] can pass into the language of knowledge and name only through translation - as many translations, so many languages - once man has fallen from the paradisiac state that knew only one language' ${ }^{96}$ - a direct pre-nominal language, one that we must transcend by translating knowledge into name, the correct name in each language - which is not the base knowledge of things as they are, but the forming of things as they should be. And what is this natural language, prior to the misreading process of naming? 'The paradisiac language of man must have been one of perfect knowledge; whereas later all knowledge is again infinitely differentiated in the multiplicity of language, was indeed forced to differentiate itself on a lower level as creation in name'. ${ }^{47}$

This multiplicity has a clear relationship with the ontological structure of objects. While he states that, 'if words meaning the same thing in different languages are arranged about that signified at their centre, we have to inquire how they allwhile often possessing not the slightest similarity to one another-are similar to the signified at their centre', ${ }^{48}$ elsewhere he writes that:

[E]very essence contains from the outset a limited-and moreover determinate-multiplicity of essences, which do not derive from the unity in a deductive sense but are empirically assigned to it as the condition of its representation and articulation. The essential unity reigns over a multiplicity of essences in which it manifests itself, but from which it always remains distinct. ${ }^{49}$

So every object admits of a finite set of alternative appearances that are accessible as the representation or articulation of that object. These are the possible perspectives on the object that are written into it; the subjective appearances that it may take. He goes on:

The multiplicity of languages is such a plurality of essences [... it] is not the product of decadence any more than is the multiplicity of peoples [...] If we interpret this doctrine in the spirit of the mystics as pointing to a revealed unity of a linguistic kind, it will mean not just that this primordial language is the one originally spoken, but that the harmony originally created by those spoken languages was of incomparably greater power than any of the individual languages could possibly possess..$^{\circ}$

\footnotetext{
45 This tradition originates in Gen.Io, where Noah's three sons go on to repopulate the earth in 70 distinct peoples. Later tradition claimed that each of these developed their own tongue and so there are 70 languages in the world, of which only the Hebrews had managed to retain the original language, along with much else.

46 'On Language', pp. 70-7I.

${ }^{47}$ Ibid., 7I.

48 'On the Mimetic Faculty', in Benjamin, W., I999, p. 721. Cf. Otiot de-R. Akiva, where each word has 70 meanings.

49 'Language and Logic', in Benjamin, W., I996, p. 273.

${ }^{5 \circ} \mathrm{Ibid}$.
} 
The primordial language that unfolded into the tongues of the world held a power unlike any of those descended from it; this single language of pure perception could not help but disperse into the different aspects of interpretation that lay dormant within it - the perspectival languages with which we now communicate - but at one time in the process of redemption we might hope to reclaim this unity and see the world again through the eyes of Adam.

Nature itself cries out for the reunification of the diffuse languages, it mourns the fallacious and abusive overdetermination that the fragmentation of terminology brings. Benjamin calls this 'overnaming', the creation of many concurrent names for single things: 'Overnaming-the deepest linguistic reason for all melancholy and (from the point of view of the thing) for all deliberate muteness. Overnaming as the linguistic being of melancholy points to another curious relation of language: the overprecision that reigns in the tragic relation between the languages of human speakers'. ${ }^{\text {I }}$

Nature, then, desires the simplicity and singularity that a return to the single language of creation - the Adamic language - would bring. In order to know the world without perspective, to know it as it is, it must be known in the primordial language. And the return to the primordial language is something that can only come alongside the messianic redemption.

In a conflation of the biblical Eden and Babel, profane language here came with the fall, the division of people into perspectives, cultures, and languages such that immediate knowledge is now no longer possible. The world itself cries out for this immediate knowledge, but it is only with the reunification of languages into one that this would be possible. The primordial semantics of the world, prior to the differentiation into object and multiple subjects, Benjamin compares to the hidden core of meaning within spoken language:

The language of nature is comparable to a secret password that each sentry passes to the next in his own language, but the meaning of the password is the sentry's language itself. All higher language is a translation of lower ones, until in ultimate clarity the word of God unfolds, which is the unity of this movement made up of language. ${ }^{52}$

The final unfolding of God's creative action is the reclamation of a diaphanous state of pure and immediate knowledge, but one which has gone through the process of division of naming - overnaming - so that all things in their fully worked-out and expressed individuality can be preserved in their final and correct state - as known, as manifest.

Abulafia also discussed the 70 languages and their messianic reunification, writing that, 'The origin of prophecy is in the address God spoke through the medium of the perfect, holy language that reached the prophets and encompassed all seventy languages'. ${ }^{53}$ Not only are the 70 languages encompassed by Hebrew, but 'each and every word that was pronounced by God, was divided into seventy languages'. ${ }^{54}$ As Idel comments, this means that returning the languages to the

\footnotetext{
${ }^{1}$ 'On Language', p. 73.

${ }^{52}$ Ibid., p. 74.

${ }^{3}$ Sheva' Netivot ha-Torah. See Scholem, G., I973, p. I 88.

${ }^{54}$ Ibid.
} 
original single entity will restore 'the divine word [...] to its primordial perfection'. ${ }^{55}$ Abulafia makes this clear in his interpretation of a famous passage from Zephaniah:

And they [the languages] will continue to be so confused until the coming of the redeemer, when the entire land will return to the only clear language, as it is written: 'For then I will turn to all nations a pure language, that they may all call upon the Name of God and serve Him with one consent, with One Name.' [Zeph.3:9]. ${ }^{56}$

However, for Benjamin, this theory was inseparable from the act of translation. There is a spirit inherent in language that translation lays bare. It is the act of translation that, in fact, evokes and demonstrates the inherent trans-linguistic spirit at the heart of all tongues, and thus speaks of their abeyant unity. There is a sublingual level where meaning is not yet put into words, which predates and precipitates every act of speech, and this can only now be reclaimed through the explicative process of translation.

\section{Conclusion}

While Abulafian language - the language of names - is the inner essential nature of reality, and that which generates the blunt forms we see, Benjamin's namelanguage is a stratum above the natural world, one created by humans as the final iteration of the world; the manifestation of the potential that always lay hidden within the material cosmos. And so, 'the name is articulated as the concentration of force within the word, embodying a cohesive expression of the essence of the bearer of a name'. ${ }^{57}$ The name translates a material substance, by focussing its unique essential energy, into the eternal, incorruptible realm of language.

Naming actually reforms the world, transmuting it from its base status as material into something transcendent: knowledge. The creation of this metaphysical stratum might then be the speaking of God's Name. The names we give all speak of, participate in, and actualize, the Name of God. This process of naming is something of a messianism for Benjamin; after the diffusion of the primordial language of pure perception into the manifold perspectives of common human language - that is, the division of simple truth into relative 'national' interpretations - Benjamin still idealizes the reunification that might come with the power of the original language. This language, however, in not knowing the difference of naming, the distance of multiple competing perspectives, can speak only of identity: it obliterates the distance between subject and object. The pure language communicates nothing at all because it is a pre-rational communion: 'in this pure language-which no longer means or expresses anything but is, as expressionless and creative Word, that which is meant in all languages-all information, all sense, and all intention finally encounter a stratum in which they are destined to be extinguished'. ${ }^{58}$

\footnotetext{
55 Idel, M., 20IO, p. I73.

${ }^{56}$ Abulafia, Sefer Shomer Mitzvah, (Trans.) Idel, M., I989, p. 26.

57 Jacobson, E., 2003, p. I3I.

${ }_{58}^{8}$ 'The Task of the Translator', in Benjamin, W., I969, p. 80.
} 
This pure language is itself the Name of God; God, who created by expressing His own intellectual being - in expressing His Name, created the fundamental strata that was to evolve into language and the languages of the world. In the reunification of human languages, we are then approaching the Naming of God that will place humanity in direct contact with the divine.

While for Abulafia knowing is a destructive activity, dissolving reality into its most base and primal state, for Benjamin it is constructive - not merely a passive reflection on the world, but the epistemic completion of it. For Benjamin, it is the human, as the namer, who epistemically seals reality into being, and who therefore elicits a material redemption by transforming the raw chaos of the material sphere into the ordered types, natural kinds and individual identities. Unlike Abulafia, for whom the messianic process must ultimately destroy the forms of reality, Benjamin's Messiah participates in the process of naming, of enwording, and sealing, as part of a partaking of divine reparation or prelation - by translating the linguistic being of things into names, humanity elevates these things into the divine sphere; we make them meta-physical. Naming draws letters together into objects, and these objects then admit something more than the material that constitutes them there is an internality, a metaphysical unity that cannot be reduced to aggregates of letters. The essence of metaphysics is identity, and in prescribing individual identity to objects, they participate in the transcendental, which is to say they are incorporated into the identity of identities: God. In becoming named, objects participate in the Name of God, that which confers the possibility of identity on all and that acts as the gravitational pull towards the manifold singularity of identities which ultimately - messianically - speak of the unity of all in the identity of God.

\section{Bibliography}

Abulafia, Abraham. Chayyei ha-Nefesh. MS Munich-BS 408. Printed edition edited by A. Gross. Jerusalem, 200 I.

- Get Ha-Shemot, (Trans.) Fabrizio Lanza, (Providence University, 2007)

—, Mafteach ha-Chokhmot. MS NY-JTSA Mic. I686. Printed edition edited by A. Gross. Jerusalem, $200 \mathrm{I}$

— Or ha-Sekhel. MS Vatican-BA ebr. 233. Printed edition edited by A. Gross. Jerusalem, 200 I.

—, Otzar Eden Ganuz. MS Oxford-BL I 580 . Printed edition edited by A. Gross. Jerusalem, 2000.

— Jerusalem, I984.

— Sefer ha-Chesheq. MS NY-JTSA Mic. I 801. Printed edition edited by A. Gross. Jerusalem, 2002.

- Sefer ha-Melammed. MS Paris-BN héb. 680. Printed edition edited by A. Gross. Jerusalem, 2002.

— Sheva Netivot ha-Torah. In Philosophie und Kabbala. edited by A. Jellinek. Leipzig, I854. I-48.

Barry, Keiran, The Greek Qabalah: Alphabetical Mysticism and Numerology in the Ancient World, (Weiser, I999)

Benjamin, Walter, Illuminations, (Ed.) Hannah Arendt, (Trans.) Harry Zohn, (Schocken, I969)

- The Origin of German Tragic Drama, (Trans.) John Oliver, (NLB, I977)

- Selected Writings vI: I9I3-26, (Eds) Marcus Bullock and Michael V Jennings, (Harvard University Press, I996)

— Selected Writings v2: I93 I-I934, (Eds) Michael W. Jennings, Howard Eiland, and Gary Smith, (Harvard University Press, I999)

Blickstein, Shlomo, Between Philosophy and Mysticism: A Study of the Philosophical-Qabbalistic Writings of Joseph Giqatila (I248-c.1322), (PhD diss., Jewish Theological Seminary of America, I983) 
Brockhaus, Richard R., Pulling Up the Ladder: The Metaphysical Roots of Wittgenstein's Tractatus Logico-Philosophicus, (Open Court, I99I)

Fossum, Jarl E., The Name of God and the Angel of the Lord: Samaritan and Jewish Concepts of Intermediation and the Origin of Gnosticism, (Mohr Siebeck, I985)

Handelman, Susan, Fragments of Redemption: Jewish Thought and Literary Theory in Benjamin, Scholem \& Levinas, (Indiana University Press, I99I)

Hanssen, Beatrice, 'Language and Mimesis in Walter Benjamin's Work', The Cambridge Companion to Walter Benjamin, (Ed.) Davis S. Ferris, (Cambridge University Press, 2004): 54-72

Idel, Moshe, Language, Torah, and Hermeneutics in Abraham Abulafia, (State University of New York Press, I989)

- Absorbing Perfections: Kabbalah and Interpretation (Yale University Press, 2002)

- 'A Unique Manuscript of an Untitled Treatise of Abraham Abulafia in Biblioteca Laurentiana Medicea', Kabbalah: Journal for the Study of Jewish Mystical Texts, I7, (2008), 7-28

— Old Worlds, New Mirrors, (University of Pennsylvania, 2010)

Jacobson, Eric, Metaphysics of the Profane: The Political Theology of Walter Benjamin and Gershom Scholem, (Columbia University Press, 2003)

Miller, Michael T., The Name of God in Jewish Thought: A Philosophical Analysis of Mystical Traditions from Apocalyptic to Kabbalah, (London: Routledge, 201 5 )

Morlok, Elke, Rabbi Joseph Gikatilla's Hermeneutics, (Mohr Siebeck, 20I I)

Procshyn, Alexei, 'Walter Benjamin's Philosophy of Language' Philosophy Compass, 9, 6, (20I4), 368-8I

Scholem, Gershom, 'The Name of God and the Linguistic Theory of the Kabbalah', (Trans.) Simon Pleasance, Diogenes, 79, (1972), 59-80; Diogenes 80, (1973): 164-94

Stern, Josef, 'Language,' 2oth Century Jewish Religious Thought, (Eds) Arthur A. Cohen and Paul Mendes-Flohr, (Jewish Publication Society, 2009), 543-5 I

Weiss, Tzahi, 'Three Traditions of the Creation of the World from Letters' (Hebrew), Kabbalah, I7, (2007): I69200

, 'On the Matter of Language: The Creation of the World from Letters and Jacques Lacan's Perception of Letters as Real', Iournal of Jewish Thought and Philosophy, I7, I, (2009), IOI-I 5

Wolfson, Elliot R., Abraham Abulafia-Kabbalist and Prophet: Hermeneutics, Theosophy, and Theurgy, (Cherub Press, 2000)

Wolfson, Elliot R, 'Abraham ben Samuel Abulafia and the Prophetic Kabbalah', quoted from, Jewish Mysticism and Kabbalah, (Ed.) Frederick Greenspahn, (New York University Press, 20I I), 68-90

Wolin, Richard, Walter Benjamin: An Aesthetic of Redemption (Second revised edition), (University of California Press, I994)

\section{Notes on contributor}

Department of Theology \& Religious Studies, University of Nottingham, University Park, Nottingham NG7 2RD, UK.

Correspondence to Michael T. Miller. Email: Michael.miller@nym.hush.com 